\title{
How the resource curse affects urban development in East Timor
}

\author{
I. M. Madaleno \\ Portuguese Tropical Research Institute, Lisbon
}

\begin{abstract}
East Timor is heavily reliant upon royalty and taxation revenues from petroleum and natural gas resources. Poor management of natural resources revenue has given ground for the nation to fall victim to the 'resource curse'. This paper provides an overview of the country's recent history whilst characterising its energy resources availability and case-studying a stressing and omnipresent urban problem: the persistence of internal displaced people (idps) living in refugee camps within Dili district. The objective of this contribution is to describe sample research conducted in the capital city of the first $21^{\text {st }}$ century nation on Earth, so as to evaluate with empirical data how the wealth of natural resources is being used both to improve East Timorese daily lives and to regenerate the urban tissue.
\end{abstract}

Keywords: resource curse, refugee camps, urban regeneration, Dili, East Timor.

\section{Introduction}

Asian tigers - South Korea, Taiwan, Hong-Kong and Singapore - are resourcepoor countries. East Timor as well as Angola, both former Portuguese colonies, are resource-rich, exhibiting poor economic growth performances and displaying high levels of poverty (see table 1). The quality of local institutions is decisive, though, for there is no curse that cannot be lifted $[1,2]$. It is widely accepted that good governance and a strong juridical and institutional framework tend to minimise the ill consequences of the mineral and energy resources privilege both on common people and on political leaders. Weak administration of revenues by contrast can lead to financial resources waste and environmental constrains on grounds of political mismanagement and corruption as on easy money availability excesses. East Timor became the first new nation of the $21^{\text {st }}$ century 
following international support to its long resistance against illegal domination by its giant Indonesian neighbour, aimed at oil and natural gas misappropriation that has been condemned by the United Nations.

This paper provides an overview of the country's recent history whilst characterising its energy resources availability and case-studying a stressing and omnipresent urban problem: the persistence of internal displaced people living in tents in refugee camps inside and around the capital city, Dili. The first aim is to address the critical question of how East Timor is dealing with the so-called 'resource curse' while analysing the institutional and legal framework of real estate ownership, and the administration of petroleum and natural gas revenues. The second objective is to describe sample research conducted in the capital city in the beginning of 2008, in order to evaluate with empirical data how the wealth of natural resources is being distributed and whether the revenue is being used to improve East Timorese daily lives.

Table 1: $\quad$ Socio-economic data per country (2006).

\begin{tabular}{|l|c|c|c|c|}
\hline Countries & $\begin{array}{c}\text { GNI per } \\
\text { capita } \\
\text { (US\$) }\end{array}$ & $\begin{array}{c}\text { External } \\
\text { Debt } \\
\text { (\% of GNI) }\end{array}$ & $\begin{array}{c}\text { Life } \\
\text { expectancy at } \\
\text { birth (years) }\end{array}$ & $\begin{array}{c}\text { Population } \\
\text { Growth } \\
\text { (annual \%) }\end{array}$ \\
\hline South Korea & 17,690 & - & 78 & 0.3 \\
\hline Taiwan & 17,230 & - & 76 & 0.2 \\
\hline Hong-Kong & 28,460 & - & 82 & 1.0 \\
\hline Singapore & 29,320 & - & 80 & 1.2 \\
\hline Portugal & 18,100 & - & 78 & 0.4 \\
\hline Cape Verde & 2,130 & 57.5 & 71 & 2.2 \\
\hline East Timor+ & 840 & - & 57 & 5.3 \\
\hline Angola+ & 1,980 & 40.9 & 41 & 2.8 \\
\hline Venezuela+ & 6,070 & 32.0 & 74 & 1.7 \\
\hline Indonesia+ & 1,420 & 49.7 & 68 & 1.1 \\
\hline Australia+ & 35,990 & - & 81 & 0.9 \\
\hline
\end{tabular}

Source: World Bank (2008).

+ Resource-Rich Countries.

\section{What is the resource curse?}

When the economy of natural resource-rich countries performs worse than those with smaller endowments, which is obviously the opposite to what one might expect, they are qualified as suffering from the 'resource curse' [3]. In a simplified manner, the resource curse refers to the inverse relationship between high natural resource dependence and economic growth rates. The underperformance is particularly acute in energy-resource exploitation dependent nations and that is the reason why oil-exporting countries are also characterised as suffering from the "paradox of plenty" or the "Midas problem" as is vividly illustrated in Angola, whose Gross National Income per capita and life expectancy at birth are lower than another former Portuguese African colony, resource-poor Cape Verde [4]. 
It is important to emphasise that natural resources possession and exploitation are not a problem per se, but the curse derives from the way mineral resources royalties and taxation are sometimes mismanaged by non-democratic governments and weak governance, and above all, the contending issue is when and if the revenue is not evenly distributed through society [5]. So another essential aspect of the 'resource curse' stems from the fact that sometimes a country's economy is performing well, as is the case of several Arab peninsula nations, in Asia, or the example of copper-rich Chile, in South America, however social cohesion is weak, sometimes with ethnical divide, leading to unfair societal inequalities [6].

East Timor got independence with an unusually heavy burden of weak institutional history, first the 461 years of colonial Portuguese presence (15141975), an Western European country located too far away from South-Eastern Asian Timor island whereabouts; next East Timorese knew a much closer and shorter dominance, only twenty-four years, a violent and depredatory Indonesian occupation, finalised with brutal death toll and burnt territory escape (19751999). International agencies have combined efforts on picking up the pieces and helping rebuild a new country, UNTAET (United Nations Transitional Authority in East Timor) having been engaged in creating productive formal institutions that could be prepared not only to take over the administration of the territory but also to engage on sound economic management and thus contribute to diminish episodes of violence, civil unrest, corruption and nepotism so common under the previous foreign colonisation period. It was not an easy solution however because UNTAET international staff and contractors were highly paid and brought inflation, prostitution and health troubles that jeopardised indigenous customs and created jealousy and new waves of civil unrest.

Following independence, on May 2002, the production and revenue patterns were concentrated on fuels, with an elected government controlling revenues from oil and natural gas extraction without proper scrutiny from neither tax payers nor adequate public awareness, due to the exiguity of the East Timorese press and scarcity of media in the territory. This paved the way to rivalry and new political forces have emerged, usually under the leadership of a nationally recognised personality, in particular military heroes that have resisted Indonesian occupation and oppression, all very eager to get their share.

A couple of favourable measures have been taken during the first elected government, though, led by a Fretilin party majority: 1) A fairer share of revenue from offshore fuel extraction has been insistently sought, over hard talks with Australia on the maritime boundaries settlement [7]; 2) A Petroleum Fund Law has been institutionalised (August 2005) in order to reduce the option for rent seeking, as a way to ensure that the pattern of public expenditures wouldn't quickly deplete resource revenues, and especially aimed at setting aside funds that could ensure future investment expenditures. It is common knowledge that not only are energy resources such as oil and natural gas non-renewable, but also that their price on the market is subject to great volatility [2]. According to Jennifer Drysdale, at the end of June 2007, the Petroleum Fund already held US\$ 1.4 billion [8]. 
Currently the most distressing event is the fact that 2007 democratic elections results have been disrespected in East Timor, with the blessing of the United Nations and Western international aid agencies, the voted parties having been unfairly represented in the new government and some (Fretilin) having been outcast from economic affairs. Has it been a penalty for their role in the harsh negotiations with Australia on oil revenues? Or was it the result of persistent rumours of corruption? In fact, following the June 2007 elections an alliance of smaller parties, whose leader is former and first President of the Republic (Xanana Gusmão), has formed a new cabinet putting the majority party (Fretilin) in opposition. As long as the democratic process is unclear and non-inclusive, it will be impossible to expect East Timor to escape the 'resource curse'.

\section{Ownership over real estate in East Timor}

The United Nations Security Council Resolutions 384 of 22 December 1975, and 389 of 22 April 1976, repeatedly recognised as an illegal act the occupation of East Timor by Indonesia. Due to the destruction of the country and the disruption of the Indonesian Public Administration during the period of organised terrorism in 1999, most real estate registry, public and private, has been lost [9].

The Constitution of the newest Democratic Republic of Timor-Leste (East Timor) unequivocally recognised the right of private ownership of land, under Section 54, but only to national citizens. Acute problems remained unsolved, resulting from the indefinition of the ownership of public and private immovable property, which gave way to further legal framework on the regime of ownership over real estate after the recognition of independence of East Timor, on 20 May 2002, and the establishment of a national government based on the results of the first democratic elections.

Most claims from East Timorese remain however unanswered and unsettled to our days, which is a rather contentious issue because the Real Estate Law established a period of one year from the date of entry into force of the legislation for mediation or administrative restitution of the respective title (Section 12, number 1), after which unclaimed private immovable assets without identified owners should be presumed to be the property of the State (Law 1, 10 March 2003, under Section 12, number 3). Furthermore, all real estate assets acquired or built up by public entities, as well as any acts of disposal of real estate assets owned by the Portuguese State as at 7 December 1975, during the period of Indonesian occupation and till 19 May 2002, were considered non existent and the property has been automatically forfeited to the newly established State of East Timor (Sections 13 to 16).

This status stems from the fact that there are known onshore petroleum and gas reserves what tends to end up on extra-precautionary measures regarding private landownership. The outcome is both the inability of the national housing market to fully rebuild damaged (mostly burnt) property in the capital city, Dili, as the exclusion of foreign investors from city regeneration; without the associated ownership guarantees no entrepreneur is interested in construction work. It is not surprising then, that apart from governmental buildings, some 
foreign embassies, UN and EU delegations as a small number of NGO's settled at Dili, very little construction work has been developed by foreigners or by nationals in East Timor.

In order to support the housing market and facilitate decent living standards for its citizens, the National Parliament approved a complementary law on the juridical regime of real estate, devised to ensure legal security within the scope of contractual relations of leasing of real property between individuals, both national and foreign [10]. Although facilitating the leasing market, the 2005 law has not resolved the basic contentious issue at Dili, because only the proprietor may lease out, and to get ownership rights resolved has been the hard question all over the capital city. At least four different cabinets have governed since the recognition of East Timor's independence and so far no one has been willing to fully resolve the real estate and landownership issues, not only in Dili but also within the half-island Timorese territory.

\section{Displaced people in Dili, the East Timorese capital city}

Timor-Leste (East Timor's official name) has been independent for more than 5 years but legacies of poverty, patterns of violence and criminality, as feelings of injustice and isolation are showing difficult to overcome. Following hard maritime boundaries negotiations with Australia, regarding the national share of revenue over the off-shore exploited oil and natural gas, whose fraction has increased from $24 \%$ in the year 2000, to $42 \%$ in 2003 and $60 \%$ in January 2006 , on April and May 2006 there were clashes between unsatisfied army officers and the police, which resulted into massacres of unarmed policemen, leading to the proliferation of street gangs of jobless young men alienated by exclusion from the benefits of independence, whereas household unemployment is of about $40 \%$, higher within residents under 25 years of age that amount to $54.9 \%$ total unemployed (see Table 2).

The 2002 elected head of the Liberation Front for Timor-Leste, Fretilin party (Alkatiri), has been replaced by the most consensual of his ministers, foreign minister and Nobel Peace prize laureate Ramos Horta, which didn't put an end to the 2006 clashes and gang turmoil. Along 2007, street fighting and house burning by youth gangs have been recurrent, feeding the internal displaced people' (idp) camps, which amounted to 53 by January 2008, when the Portuguese Tropical Research Institute conducted a scientific mission to Dili, the East Timorese capital city.

Both the 2006 riots and the 2007 gang clashes resulted into the regrettable loss of lives; interviews to UN officers have revealed that more than 150,000 people have been displaced. Also this has not been the first instance people from East Timor have been evicted from their homes since 1999, even though this time the vast majority accounted for were from the District of Dili. The survey extracted by the Portuguese Tropical Research Institute (IICT), in January 2008, to 5 of the 53 refugee camps that persist in the capital's district, gave the more conservative estimate of 50,000 displaced people. It is more consistent with 2004 census data of 175,730 residents for the district of Dili, and 64,574 for central 
Table 2: $\quad$ Population per household and economic activity in East Timor.

\begin{tabular}{|l|c|c|}
\hline \multicolumn{1}{|c|}{ Economic Activities } & Households & $\%$ \\
\hline Government employed & 17,412 & 3.3 \\
\hline UN delegations & 3,121 & 0.6 \\
\hline NGO's & 6,509 & 1.25 \\
\hline Subsistence farming & 244,622 & 47.0 \\
\hline Fishing & 1,367 & 0.3 \\
\hline Formal trade & 6,575 & 1.26 \\
\hline Informal trade & 3,468 & 0.7 \\
\hline Artisans & 1,012 & 0.2 \\
\hline Mining and oil workers & 209 & 0.04 \\
\hline Armed forces & 1,035 & 0.2 \\
\hline Police officers & 2,150 & 0.4 \\
\hline Health staff & 1,128 & 0.21 \\
\hline Teachers & 6,691 & 1.3 \\
\hline Unemployed & 211,261 & 40.6 \\
\hline Not elsewhere included & 13,705 & 2.63 \\
\hline Total households & 520,265 & 99.99 \\
\hline East-Timorese Population & 923,198 & - \\
\hline
\end{tabular}

Source: Census of Population and Housing (2004).

Dili [11], than the United Nations figures but we admit the riots have been pressing on Dili's inhabitants and over demanding in aid.

The idp refugee camps are small groupings that offer security, defence, selfhelp, basic food and shelter, enabling evicted or simply hunger-driven urban residents to coexist peacefully, harmoniously and slightly more prosperously than in their original neighbourhoods and shacks. There are strong social and political bonds between the idps based on survival needs, on party affiliation, on historical loyalties, on hierarchical relationships, and on ethnic affinities. There are thirteen major ethnic groups in East Timor but the great divide is between the Lorosae (East) and the Loromonu (West). The first are considered better workers and the last come from rice and coffee rich areas, and are more numerous in the camps. We found the idp camps tightly knit organisation to be based on fear. The same fear that drives them away from a burnt building or troubled neighbourhood keeps them in the idp camp where the very basic needs are met, where there is a sense of belonging, where human relationships are easily met and interpersonal ties encouraged.

Why have idp refugee camps mushroomed within the capital city of East Timor since 1999? 1) There are a good number of damaged buildings in Dili (30\%), all due to violence; 2 ) There is political indefinition as to land and house ownership; 3) The State still hasn't developed proper social structures, hasn't legitimated political organisations, and failed to create sound economic institutions. Complete resolution of these problems is a pre-requisite both to build a nation and to regenerate the capital city. The urban tissue has to be healed, the sooner the better, for each physical scar the cityscape has represents a 
multiplication of human scars $[12,13]$. While no strong public institutions exist, informal structures and organisations tend to replace the weak or failed State, giving sustainability and ensuring stability to more vulnerable urbanites.

Table 3 clearly displays total internal displaced people from each of the five researched camps; in four of them interviewed residents have declared to live in tents since 2006 but the Cathedral refugees have only been displaced from their neighbourhood in the beginning of 2007 by martial arts rival gangs of youngsters. No official numbers exist for aid is clearly overestimated and previous attempts from donors to characterise idps have been unsuccessful. Because we knew the task would be difficult, even dangerous, we've sample interviewed every camp coordinator plus five other residents on different occasions and listened to them separately, in order to cross examine data.

For more than one year idps have been fed by foreign aid, shared by the United Nations and the European Commission Humanitarian Office (ECHO), plus Norway Cooperation, the Australian and the East Timorese governments, the last three being in charge of an unclear percentage of the budget. The whole system is so much unaccountable that it has been impossible to get a sound picture of the status quo. The lack of 'accountigisation' has been a surprising outcome of the IICT assessment of aid to East Timorese urban idps, as it is consensual that good management principles must include written contracts, budgets and account publication as normal codes of conduct, both for national governments and international organisations [14].

Table 3: Internal displaced people in sample researched refugee camps.

\begin{tabular}{|l|c|}
\hline \multicolumn{1}{|c|}{ Refugee camps } & Number of Residents \\
\hline Idp camp Timor Hotel & 2,500 \\
\hline Idp camp Motael School & 350 \\
\hline Idp camp Motael Church & 2,550 \\
\hline Idp camp of Sional (ex-China consulate) & 500 \\
\hline Idp camp Dili Cathedral & 1,266 \\
\hline Total sample researched & 7,166 \\
\hline
\end{tabular}

Source: IICT survey (January 2008).

Regarding the European Commission contribution, it has been easier to get a fair range of data: Water and sanitation (one hygiene kit per person, water tanks and sanitation facilities for 16 refugee camps); logistics support (sub-contracted to NGOs); a number of 400 tents provided to idp families; and food distribution ( $8 \mathrm{~kg}$ of rice, $3 \mathrm{~kg}$ of beans and $1 / 2$ a can of oil, per person and per month). Funded under a so-called emergency aid plan that totals 8 million Euros, 6 millions had already been given away in a one and half year period. In January 2008 ECHO was trying to renegotiate a fairer share of the 15 million dollars budget the East Timorese government had approved for 2008, exclusively targeting Dili's idps, insisting on resettlement and housing for the refugees, instead of sustaining them on improvised urban camps. The situation has not been solved so far mainly because the real estate issue remains unsolved, as explained before. 
Nation-building certainly requires time, patience, trial and error; normal civic life experiences were inexistent whilst such a particular people as the East Timorese lacks memories of democracy for generational record is of dictatorial regimes. It will be obviously a long learning process of living together, of accepting ideological differences, of acquiring the wisdom of a democratic culture. Daily life is quite hard to cope with, for social and economic policies have been mislead by international institutions norms, aimed at minimising the public employment sector and stimulate subcontracts to private companies, mostly foreign. What is consensual in Washington and Brussels is often inadequate abroad... [15]

East Timorese public budget and national economy is $90 \%$ dependent on oil and gas revenues, based on foreign off-shore powerful companies that employ very few unskilled or poorly prepared Timorese labourers. Indonesian public officers left a burnt territory in 1999 as well as a largely unqualified population behind, for long deprived of proper education and technical skills. Incentives to foreign investment for job creation have been scarce and ineffective.

Once real estate is mostly public and the national housing system sector almost inexistent in East Timor, because families that live in enduring buildings pay a 10 dollar rent to the State, they pay school fees for their children's education, they see rice prices rising continuously, all provoked by the demanding presence of the same international institutions brought to help economic development, to institute political and military stability, such as United Nations delegations, the World Bank, the European Commission Humanitarian Office, as a number of Non-Governmental Organisations and bilateral aid agencies, life became unbearable for most urban residents. Foreigners in Dili totalled around 5,500 in the 2004 census but they've increased ever since due to law and order reinforcement after the 2006 riots and more recently during the February 2008 turmoil. New contingents of UN led military and police forces have arrived East Timor, mostly Australian but also paramilitary Portuguese forces (GNR).

Food prices also rise because domestic production is shrinking, due to civil unrest, urban migration, insufficient technical training, inadequate seeds and fertiliser inputs, bad infrastructure conservation and deficient means of transportation, leading to increasing imports of all sorts of commodities. Only a very small fraction of oil and natural gas revenue has entered in the crippled local economy so far, the bulk of it going to corrupt officers, paid for foreign consultants, to foreign defence forces, to imported goods and services.

It was no surprise to acknowledge that a good share of the thirty idps interviewed had a house to return to $(60 \%)$, a small group even had a job $(10 \%)$, as public officers and running informal businesses. Seen by some foreign consultants as an unfair survival strategy, for idps living in the refugee camps are fed by international aid, and are also acknowledged as being closely related to political opposition and outcast military groups - the Fretilin party or major Reinado (the leading 2006 army insurgent, killed in the February 2008 riots) truth is the eternal mushrooming of refugee camps all over Dili is rooted on rice price speculation, which explains that $71 \%$ of the urban population has deficient 
food consumption [16]. Housing is also unaffordable to the $40.6 \%$ East Timorese households with no income, people that lack potable water, electricity and telephone services, a situation particularly acute among jobless youngsters.

\section{Conclusion}

Human security results from the option of becoming an idp, an internally displaced person, totally dependent on foreign supplied humanitarian assistance. Human security has seven components that are crucial pre-requisites for safeguarding freedom of disadvantaged groups: 1) economic security, 2) food security, 3) health security, 4) environmental security, 5) personal security, 6) community security, 7) political security. Stress on territorial security only is rather limitative, because sustainable human development has to be achieved through people's individual security [17].

Harford and Klein argue aid is as much a curse as natural resources are. Reasons are identical such as: aid money being lost before reaching the intended recipients; both aid and oil rents having negative effects on democratic institutions because they fuel corruption and nepotism; both aid and oil being detrimental for local political and economic institutions whilst they lead to rent seeking and accommodation processes rather than to innovation, reform, and investment options; finally, aid slows the growth of business and labour intensive industries, as is clearly the case with East Timor and its capital city, Dili, because rice, oil and beans given away in the 53 refugee camps are imported and thus no wealth results to the recipient economy and no East Timorese jobs are created nor maintained through aid, just dependency [3].

Our conclusion is the resource curse affects negatively urban development in East Timor as much as long-term aid inflows. Should East Timorese government create more public jobs in infrastructure reinstatement and on house reconstruction, as should East Timorese Parliament review the real estate law, and part of the unemployment, young population's underemployment, the civil unrest, food sufficiency and the contentious shelter problems would be solved in the city of Dili.

\section{References}

[1] Sachs, J. D. and Warner, A. M., "The Curse of Natural resources". Economic Review, 45, pp. 827-838, 2001.

[2] Mehlum, H., Moene, K. and Torvik, R. Institutions and the Resource Curse. Economic Journal, 116, pp. 1-20, 2006.

[3] Harford, T. and Klein, M., Aid and the Resource Curse. Public Policy for the Sector, 291, ed. The World Bank: Washington, pp. 1-4, 2005.

[4] Karl, T. L., Understanding the resource curse. Covering Oil, ed. Tsalik, S. Schiffrin, A., Open Society Institute: New York, pp. 21-24, 2005.

[5] Auty, R., Sustaining Development in Mineral Economies: The Resource Thesis. Routledge: New York, 1993. 
[6] Madaleno, I. M., The Privatisation of Water and its Impacts on Settlement Traditional Cultural Practises in Northern Chile. Scottish Geographical, 123 (3), pp. 193-208, 2007.

[7] National Parliament, On the Petroleum Development of Timor Sea (Tax Stability). Law $n^{\circ} 4$ of the $1^{\text {st }}$ July 2003. //:www.unotil.org/legal/RDTLLaw/index-e.htm

[8] Drysdale, J., The institutional challenges of managing Timor-Leste's revenue. The Crisis in Timor-Leste: Understanding the past, the future, ed. Shoesmith, D., Charles Darwin University: Darwin, pp. 77-83, 2007.

[9] National Parliament, The juridical regime of real estate - part I: Ownership real estate, 2002. http//:www.unotil.org/legal/RDTL-Law/index-e.htm

[10] National Parliament, Juridical regime of real estate - part II: Leasing between individuals, 2005. www.unotil.org/legal/RDTL-Law/index-e.htm

[11] DNE, Census of Population and Housing 2004. National Directorate of Statistics and United Nations Population Fund: Dili, 2004.

[12] Clark, D., Urban World / Global City. Routledge: New York, 2003.

[13] Cotton, J., The Crisis of the Timor-Leste State in Comparative Perspective. The Crisis in Timor-Leste: Understanding the past, imagining the future, ed. Shoesmith, D., Charles Darwin University: Darwin, pp. 13-21, 2007.

[14] Stewart, K., Designing good urban governance indicators: the importance of citizen participation and its evaluation in Greater Vancouver. Cities, 23 (3), pp. 196-204, 2006.

[15] Chomsky, N., Rogue States: The rule of force in world affairs. Verso: London, 2000.

[16] Poverty Assessment Project, Timor-Leste: Poverty in a new nation, analysis for action. United Nations/ The World Bank / The Government of East Timor: Dili, 2003.

[17] Hasegawa, S., Inclusive democratic governance for human security and human development as viable security option for Timor-Leste. Proceedings of National Seminar on Regional Security Options for Timor-Leste, ed. United Nations: Dili, pp. 1-16, 2002. 